\title{
Factors Determining Potato Market Outlet Choices of Members' of Primary Agricultural Cooperative Societies: The Case of Jeldu Woreda, West Shoa Zone, Oromia Regional State, Ethiopia
}

\author{
Dereje Hailu Korsa $^{1} \quad$ Professor.S.Nakkiran ${ }^{2}$ \\ 1.Department of Cooperatives, College of Business and Economics, Mizan-Tepi University, Ethiopia \\ 2.Department of Cooperatives, Institute of Cooperatives and Development Studies, Ambo, University, Ethiopia
}

\begin{abstract}
Potato (Solanum tuberosum L.) popularly known as 'The king of vegetables', which is the fourth most important food crop next to maize, wheat and rice worldwide. The choice of market outlet for smallholder potato producers is very important, since potato is perishable product and more demanded by the society. The present study examines the major 'Factors determining potato market outlet choices of members': of primary agricultural cooperative societies: The study employed survey methods as a research approach. A random sample of 159 members of cooperatives societies has been selected for interview. Both descriptive and econometric methods have been employed for data analysis. Results from descriptive statistics shows that $69.8 \%$ of the total members have chosen non-cooperative firms as their potential market outlet for their potato produces, while $30.2 \%$ of them have chosen cooperatives as their outlets since the majority of the members have witnessed that noncooperative firms have provided relatively fair price to their potato produce. The logistic regression model with p-value of 0.001 has witnessed that there is statistically significant difference between cooperatives and noncooperative firms in market outlet choice. Moreover, results from logistic regression model reveals that extension service offered by the cooperatives, transportation facility, distance from markets, distance from cooperatives, access to credit and belief on cooperatives have p-value of less than $5 \%$ and hence are found to be the most determining factors of members market outlet choice in the study area. The study shows that cooperatives failed to be chosen as premier and potential market outlet by members in the study area. Therefore, the researcher suggested that institutional capacity of cooperatives should be strengthened in order to face unfair competition, influence other firms to behave competitively in the market place, to win trust of members and thereby bring about real participation in potato market and ensure sustainable growth.
\end{abstract}

Keywords: Determinants, Logistic regression model, Market outlet, Potato, Study area

DOI: $10.7176 / \mathrm{JMCR} / 73-01$

Publication date: November $30^{\text {th }} 2020$

\section{Introduction}

Cooperative is an important tool of living, since it enables individuals to achieve heights which cannot be reached in isolation. This can be proved by Rochadle Pioneers (1844) through their friendly association. It is a special group of people with mutual interest to solve their individual problems through common efforts and ultimately attaining economic and social empowerment to the group members and the community (Alemu \& Gebreyohannes, 2016). A cooperative is distinguished from other businesses by its adherence to a set of operating rules, called cooperative principles (Kirub, 2008). Cooperation is an age-old tradition that runs through the history of Ethiopian society. For centuries, the spirit of self-help has been an integral part of farming communities. In line with the government's plan to privatize business, NGOs ${ }^{\text {ee }}$ funding is helping to restructure these cooperatives to become farmer owned and controlled, democratic and transparent (FCA, 2005).

Agriculture is one of the pillars of the Ethiopian economy and the overall economic growth of the country is highly correlated to the success of agricultural sector (Dejene, 2014). The agricultural sector accounts for nearly $46.7 \%$ of the GDP and provides employment for $85 \%$ of the population (Tekle, 2008). Ethiopian agriculture is dominated by subsistence oriented, natural resource intensive, low input low output; rain-fed farming system (Shewaye, 2016).

Potato is one of the agricultural crops and more than 320 million tones are being cultivated annually on 20 million hectares of land worldwide (FAO, 2010). It was first introduced in Ethiopia by a German botanist called Schimper in the 19th century Horton (1987), as cited by (Kahsay Gebresslasie et al., 2015). In Ethiopia, potato (Solanum tuberosum L.) can play an important role in improving food security and cash income of smallholder potato growers (Tufa et al, 2015). As the population grows rapidly, increased productivity of potatoes is used to meet the growing demand (Gildemacher, 2012). The potential for high yield, early maturity, and excellent food value give the potato great potential for improving food security, increasing household income, and reducing poverty (Kolech et al., 2015).

According to (Ephrem, 2014) agricultural marketing cooperatives are a significant form of business enterprise. Despite good agricultural product in the past years in Ethiopia, there were various constraints in 
agricultural product marketing systems such as limited market information and lack of transportation facilities (Fayera \& Benyam, 2019). Proper functioning market will only occur when enough markets and efficient market outlets exist for the sale of produced output and no single entity can individually influence the price (Edossa et al., 2019)

The potato holds great promise for improving the livelihoods of millions of smallholder farmers in the highlands of Ethiopia. The lack of market participation that many agricultural households face is considered to be a major constraint to combating poverty (Wainaina, 2016). The weak performance of the agricultural cooperatives in conducting of marketing (both inputs and outputs markets) in Ethiopia has been portrayed in various studies as a major impediment to growth in the agricultural sector and the overall economy. It is found that agricultural cooperatives have had limitations by meeting efficiently the needs of their farmer members (Dawit, 2005). Thus, the major challenge facing the agricultural cooperatives is how to operate and meet the needs of the members efficiently and effectively keeping in mind the basic principles of cooperatives.

In the study area, potato is the main crop which comes first in terms of area coverage as compared to other vegetables crops produced in Jeldu Woreda. Farmers produce potato for family food consumption and as source of income. Despite the production potentials and importance of potato crop for the country as well as the study area, there has been limited performance of farmers in potato marketing. In order to maximize the benefits producers may earn, they have to make appropriate decisions as to where they should sell their potato. However, there are several factors that determine members' decision to choice appropriate market outlet for delivering their products to the market. Identifying these factors and available market outlet choice in the study area is very important in terms of identifying possible areas of interventions that may help farmers to maximize benefits out of their potato production and marketing activities.

Previous studies on members' choices of marketing outlet found that factors such as quantity of sold, frequency extension contact, production experience, and distance to nearest market, market information about each outlet, cooperative membership, and trust in buyers determine market outlet choice (Tarekegn et al., 2017). Honja et al., (2017) found that family size, distance to the market, quantity of produced, access to non-farm income and price offered are the significant determinants of the choice of wholesale market outlet. (Ahmed et al., 2017) also found that gender of household head, education level, market distance, size of land, production experience, store time, access to extension and labor force of household member found to affect market outlet choice. (Wosane et al., 2018) also revealed that quantity of produced, farming experience, extension contact, year of schooling, bargaining power of the producer; post-harvest value addition, market distance, and livestock ownership had influence on choices of the market outlet. (Jebesa, 2019) noted household characteristics, transaction costs, product characteristics, household asset and trusts on buyers were determinants of smallholder farmers' market outlet choice in Ethiopia.

However, despite a wealth of literature on the market outlet choices among members/producers, the relevance of these factors on market outlet choice has not extensively investigated in Jeldu Woreda. Therefore, the researcher was conducted his finding on Jeldu Woreda, potato cooperatives societies in order to identify whether or not the same factors were there with other area that were already studied before.

Finally, other various studies were conducted on the factors determining market outlet choices in different countries. However, majority of the past empirical studies that were conducted on the factors determining market outlet choices in different regions are not similar, and the issue that was identified as a problem in the previous studies may not issue in the study area. Therefore, this study was aimed to identifying and examining factors determining potato market outlet choices of members' primary agricultural cooperatives societies in Jeldu Woreda of West Shoa Zone, Oromia Regional State, Ethiopia.

\section{Methodology of the Study}

\subsection{Description of the study area}

Jeldu Woreda, in which the study was conducted, is located about $115 \mathrm{~km}$ west of the capital city of the country, Addis Ababa and $72 \mathrm{~km}$ East of Ambo town, the capital of western Shoa Zone of Oromia region. It is bordered by Meta Robi and Ejere district in East, Gindeberet district in North, Dendi district in South and Ambo, Ilfeta and Cobi in west. The total area of the district is 139,389 hek, of which annual crops cover 64,500 hek and the remaining land is allocated for grazing, forest and other purposes. The annual rainfall of the study area ranges from $812-1699 \mathrm{~mm}$ with an annual temperature of $17-25 \mathrm{C}$. The study area has total population of 199,563 of which 97,786 are male and 101,777 are female. Moreover, among these 185,622 and 13941 live in rural and urban areas respectively.

The administrative map and location map of the Woreda are presented in figure below. 


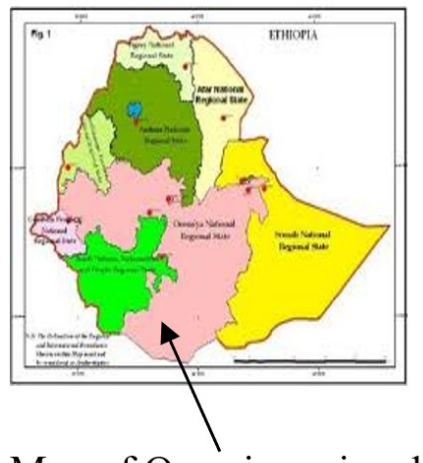

Map of Oromia regional state

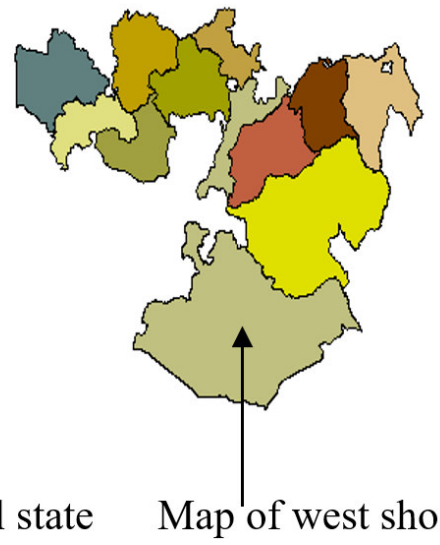

Map of west shoa Zone Map of Jaldu Woreda

\subsection{Sampling Techniques and Sample Size Determination}

In the study area, from the total six agricultural cooperative societies, three primary agricultural cooperative societies were selected by purposive sampling technique depend up on; the longevity of the cooperatives societies, the number of members of the societies, availability of required data or information and potentiality of potato suppliers in the members. Accordingly, Gudina Waqi, Gamachisi and Darara (WB Moosee) cooperatives societies were selected randomly. There are about 459, 175, and 80 members in Gudina Waqi, Gamachisi and Darara (WB Moosee) cooperatives societies, respectively. Probability Proportional to Size (PPS) was employed, to reveals the gender involvement. Finally, the study was employed simple random sampling technique to select the sample of members. The sample size of the study or the number of member respondents was determined by using Yamane (1967) sampling design formula: Accordingly, the sample size of the study or the number of member respondents was determined by using Yamane (1967) sampling design formula:

$$
\mathbf{n}=\frac{N}{1+N\left(e^{2}\right)} \quad \text { Where:-n= Denotes sample size }
$$

$\mathbf{N}=$ Denotes total number of members in the selected cooperatives (714) and $\mathbf{e}=$ Denotes the desired level of precision (taking 7\%). Therefore;

$$
\mathrm{n}=\frac{714}{1+714\left(0.07^{2}\right)}=159
$$

\subsection{Types, Sources and Methods of Data Collection}

To conduct this study, both qualitative and quantitative types of data were used. Qualitative data collected may include demographic, socio-economic and institutional characteristics of the selected members of cooperatives in the study area. Quantitative data like age of the members, quantity produced, price of product in unit of measurement, distance to the nearest market and distance from cooperatives were collected.

To generate sufficient information for this study, both primary and secondary data was used. The primary data was collected from the sampled respondents both male and female (sampled cooperative members; committees and experts of the study area cooperative societies; promoters of Woreda and Zonal cooperative promotion offices; management committees and active members. The major sources of secondary data were: profile of cooperatives societies of Jeldu Woreda, profile of primary agricultural cooperative societies; Woreda and Zonal cooperative promotion offices; Zonal and Woreda agricultural offices.

In this finding, questionnaires, key informant interview (KI) and focus group discussion (FGD) were the major instruments for data collection.

\subsection{Method of Data Analysis}

In order to analyze the collected data, descriptive and econometric model was used. Descriptive statistics such as Tables, percentages and frequencies was applied. The binary logit model was used to analyze the determinants of market outlet choices of cooperative members.

The reason why binary logistic regression was selected for this study over the other models was because of it has some advantage over the others in the analysis of dichotomous outcome variable in that; logit analysis produces statistically sound result, the independent variable and dependent variable don't have to be normally distributed, the logit analysis provides results which can be easily interpreted

Binary Logistic regression is a useful way of describing the relationship between one or more independent 
variables and a binary response variable, expressed as a probability, that has only two values, The dependent variable in this study was dummy variable (binary), which takes the value zero or one depending on whether or not a members were selling to their cooperatives or not selling to their cooperatives. However, the explanatory variables were can be either continuous or dummy.

\section{Model Specification}

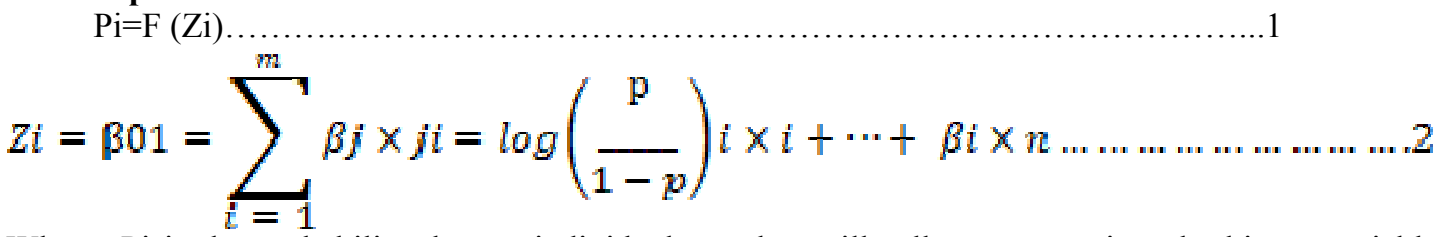

Where, $\mathrm{Pi}$ is the probability that an individual member will sell to cooperative, the binary variable, $\mathrm{Pi}=1$ for members selling their produce to cooperative and $\mathrm{Pi}=0$, for not selling.

$\mathrm{Zi}$ is estimated variable for the ith observation; $\mathrm{F}$ is the functional relationship between $\mathrm{Pi}$ and $\mathrm{Zi}$. $\mathrm{i}=1,2,3 \ldots \mathrm{m}$ are observation on variables of market outlet, $\mathrm{m}$ being the sample size 159 . xji -is the jth explanatory variable for ith observation $=1,2, \ldots . \mathrm{n}$. $\mathrm{Bj}$ is a parameter,

$\mathrm{j}=0,1, \ldots \mathrm{n}$ where $\mathrm{n}$ is the total number of explanatory variable. The logit model assumes the underlying index; $\mathrm{Zi}$ is a random variable that predicts the probability of the members selling to cooperative.

$$
\begin{aligned}
& P_{i}=\frac{1}{1+e^{-r}} \text {.". } \\
& 1-\mathbf{P} 1=\frac{1}{1+e^{q !}} \text {. }
\end{aligned}
$$

If $\mathrm{pi}$ is the probability of members selling their produce to cooperative then (1-Pi) is otherwise. If the disturbance term $\mathrm{Ui}$ is taken in to account the logit model becomes

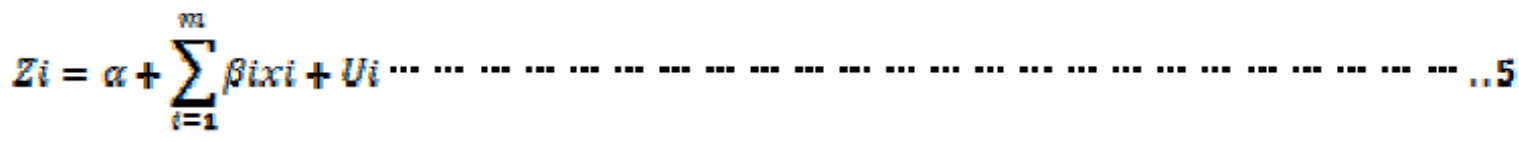

\subsection{Independent and Dependent Variables Dependent Variable}

In this study, the dependent variable was Potato market outlet choice of members': The dependent variable is a dummy variable that represents potato market outlet choice of members'. Cooperatives are assumed to be the right market outlet for members ${ }^{\text {ee }}$ produce. Hence, the dependent variable assumes the value 1 if members ${ }^{\text {ee }}$ market outlet choice is cooperatives, and unless and otherwise 0 .

\section{Independent Variables}

Age, Sex, Education, marital status, dividend payment, price, Mode of sale, quantity produced, market information, belief on cooperatives, training, access to credit, extension service, transportation facility, storage facility, distance from cooperatives and market.

\section{RESULTS AND DISCUSSIONS}

\subsection{Potato Market Outlet Choice of members' (Dependent Variable)}

The potato market outlets of the members in the study area were cooperatives and non-cooperatives like consumers, petty traders, retailers and wholesalers. The results of finding show that $69.8 \%$ of respondent choose non-cooperatives market outlet for their potato product while $30.2 \%$ of respondent prefer cooperative as their outlet for their products. This shows that the majority of the members ${ }^{\text {ee }}$ choice non-cooperatives as market outlet than cooperatives market outlet because of different reasons.

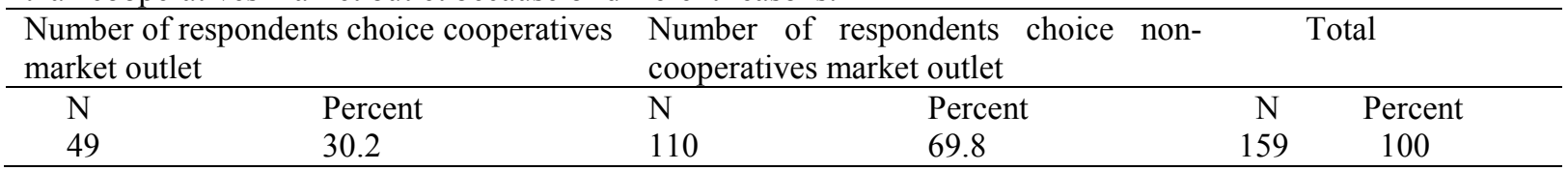

Totally, 159 household heads were considered in this study. The results of this research indicate that most of the respondents' age falls between 44-56 age categories were choice the cooperatives market outlet (31 or $63.3 \%$ ) respondents and this show that the members whose age was above 43 and less than 57 were better to choose the cooperative market outlet choice.

From the total respondents of 159 only $13.84 \%$ of them were female while $86.16 \%$ of them were male. From those who sold their potato product to cooperatives $83.7 \%$ of them were male and the rest 16.32 were 
female. And from those who sold to non-cooperative market outlet $87.3 \%$ were male and $12.72 \%$ were female.

$85.53 \%$ households were married, $11.94 \%$ were single, $1.9 \%$ were divorced and the remain $0.62 \%$ were widowed. Of the members who were selling their potato to cooperatives, $81.3 \%$ were married and the remaining $12.4 \%, 4.1 \%$ and $2 \%$ were single, divorced and widowed respectively. While among the members who were selling their potato to other than cooperatives $11.81 \%, 87.3 \%, 0.909 \%$ were single, married and divorced respectively.

$3.14 \%$ of the respondents were found in illiterate while $30.81 \%$ of them were found in $1-4$ while $37.73 \%$ of them were found in 5-8 and 21.4\% were found in high school. Among the total members' respondents who were selling potato to the cooperatives, $14.3 \%, 36.73 \%, 42.9 \%$ and $6.12 \%$ were grade $1-4,5.8$, high school and others respectively. While from the total members' respondents who did not selling their product to the cooperatives, $4.5 \%, 38.2 \%, 38.2 \%, 11.82 \%$ and $7.3 \%$ were illiterate, $1-4,5-8$, High school and others respectively.

$77.98 \%$ of the respondents were not getting credit service from cooperative, while only $22.01 \%$ of respondents were getting the service. The reason why they could not get the service was the cooperative is not offering the credit service equal to the demands of the society or the credit is not adequate to operate the members activities. This reason can be the cause for preference of non-cooperative market outlet rather than cooperative firm because non-cooperative market outlet was providing credit service before harvest for the members.

$79.8 \%$ members replied that they were not getting training service by market expert, development agents and from any other of the district while only $20.12 \%$ of members ${ }^{\text {ee }}$ take service of training out of the total respondents.

$12.57 \%$ of respondents were getting the accessibility of extension service while $87.42 \%$ of respondents were not getting the accessibility of extension service.

$27.67 \%$ of respondents obtain full market information from cooperative outlet was while $72.32 \%$ was given by no-cooperative market outlet. Due to lack of reliable market information, members were failing to negotiate better on the prices of their products and thus are paid lower prices.

$71.69 \%$ of them were not trusting on cooperative while only $28.3 \%$ of the respondents were trust on cooperative due to mismanagements and weak cooperative governance, absence of transparency and accountability among cooperative leaders and ordinary members have significant effect on market outlet choice.

$20.75 \%$ of the respondents were selling their potato in cash while $79.24 \%$ of the respondents selling their potato in credit. It was found that from the total respondents, who were selling to the cooperatives, $46.93 \%$ of them were selling on credit basis and $53.06 \%$ of them were selling on cash basis.

From respondents who were selling their product to cooperatives, 46.93 of them received dividend from cooperatives while 53.06 of them did not received dividend from the cooperatives.

$83.01 \%$ of the respondents reported that non-cooperative market outlet offer fair price while about $16.98 \%$ of the respondents reported that cooperative offer fair price for members.

the members who were far from market were mostly choice cooperative market outlet means that members whose far $11-15 \mathrm{~km}$ from the market sold their product than members who were far $5-10 \mathrm{~km}$ from the market because they choice the nearest market.

$41.509 \%$ of the members travel $2-5 \mathrm{~km}$ to reach the place of cooperative while $55.97 \%$ of them travel $6-9 \mathrm{~km}$ distance from cooperatives and has statistical significance effect at $\rho$-value of less than $5 \%$.

The result of this study shows that, there was no transport facility given to the members from cooperatives. Some of the reasons are; cooperatives had very low capital to own vehicles and transport rent is too high.

Good storage facilities reduce loss of product and importance of product selling and maintain the physical state of the product. Cooperatives with good storage facility for their members encourage members to choose cooperatives as a prime market outlet. It was found that, from the collected data most of the members were not get storage facility from cooperative to store their potato. 
Statistical result for binary logistic model

\begin{tabular}{lllllll}
\hline Independent Variables & B & S.E. & Wald & df & Sig. & Exp(B) \\
\hline Marstatus & 2.50 & 2.7 & 1.716 & 1 & .708 & 6.98 \\
EdU & .188 & 2.628 & .01 & 1 & .831 & 2.198 \\
Gend & 2.550 & 1.508 & 5.724 & 1 & .810 & 7.16 \\
Acctocdit & 3.722 & 2.818 & .000 & 1 & $.036^{* *}$ & 12.866 \\
Distfromcoop & 4.376 & 2.15 & 8.282 & 1 & $.001^{* *}$ & 17.844 \\
Belfoncoop & .46 & .254 & 6.504 & 1 & $.010^{* *}$ & 2.516 \\
marktinfo & .712 & .88 & 1.308 & 1 & .317 & 2.856 \\
Extservice & 5.648 & 3.074 & 6.75 & 1 & $.000^{* * *}$ & 33.688 \\
Modofsale & 2.374 & 4.674 & .516 & 1 & .446 & 6.554 \\
Divdend & 4.976 & 3.036 & 5.37 & 1 & $.081^{*}$ & 7.166 \\
price & .658 & 1.586 & .344 & 1 & .710 & 2.78 \\
Transpfacility & 5.354 & 2.716 & 7.77 & 1 & $.000^{* * *}$ & 29.082 \\
Storefacility & 3.02 & 1.892 & 5.096 & 1 & $.063^{*}$ & 9.058 \\
Training & 1.063 & .914 & .915 & 1 & .120 & 2.115 \\
Distfromrkt & .712 & .474 & 4.498 & 1 & $.000^{* * *}$ & 12.856 \\
constant & 2.766 & 5.34 & .536 & 1 & 0.000 & 15.134 \\
\hline
\end{tabular}

Variables entered on step 1: Marstatus, EdU, Gend, Belfoncoop, marktinfo, Extservice, Modofsale, Divdend, price, Transpfacility, Acctocdit, Training, Storefacility, Distfromcoop and Distfromrkt.

$* * *, * *$ and $*$ Significant at $1 \%, 5 \%$ and $10 \%$ probability level respectively

$\operatorname{Exp}(\mathbf{B})$ is the predict changes in odds for a unit increase in the predictor.

Extension service: it is negatively correlated with the dependent variables and statistically significant at $1 \%$ significance level $(\mathrm{p}<0.000)$. This indicates that members obtaining regular cooperatives extension service have developed their knowledge or awareness towards cooperatives market outlet. This result is consistent with Mekonin, (2017) extension services can enhance households' skills and knowledge, and link households with technology and choice of markets. The odds ratio for access to extension service indicates that with the assumption of other things remain constant, the probability of choosing cooperatives market outlet increases by factor of 33.688 as extension contact increases by one unit.

Transportation facilities: It was observed in the analysis model, transportation facilities had a significant effect at $1 \%(\mathrm{p}<0.000)$ and positive association with cooperatives market outlet choices. The odds ratio for transportation facilities indicates that with the assumption of other things kept constant, the probability of choosing cooperatives market outlet increases by a factor of 29.082 as transportation facilities increases by one unit. This result is consistent with Shewaye (2016); the closer a household farm or house to all weather road, the more will be the transportation facilities access.

Distance from market: in accordance with expectation, distance from market of the members affects members cooperatives market outlet choices positively and significant at $1 \%$ significance level $(p<0.000)$. That is the unit increase in distance from market of agricultural market result in an increase of members chooses cooperatives as market outlet. The implication is that by if the members far away from the market they are initiated and selling potato through cooperatives more and the vice versa. This result is line with Fayera \& Benyam (2019), as the distance to the nearest market increases by a unit; it decreases potato supply to cooperatives.

Distance from cooperatives: statistically significance at $5 \%$ significant level $(p<0.001)$. The implication is a unit increase in members' distance from cooperatives on their cooperatives will decrease the likelihood of that members will choose cooperatives as market outlet by the value of the odds ratio 17.844 .

Access to credit: As the access to credit of the respondent increase by one unit, the probability of choosing cooperatives as market outlet increases by a factor of 12.866 times. This means members who obtain access to credit more had 12.866 times more selling potato through cooperatives than those do not obtain access to credit.

Belief on cooperatives: statistically significant at $5 \%$ significance level $(\mathrm{p}<0.010)$. The result of binary logistic regression shows that there were negative relationship between belief on cooperatives and potato market outlet choices of members. This means as the members do not belief on cooperatives will decrease the likelihood that members will choose cooperatives as market outlet increases by the value of odds ratio 2.516 .

Dividend: statistically significant at $10 \%$ significance level $(\mathrm{p}<0.081)$. This indicate that a unit increase in the payment of surplus to members through dividend will increase the likelihood that members will choose cooperatives as market outlet increases by the value of odds ratio 7.166. This is similar with the study of (Tesfaye and Dorsey, 2005), the payment of patronage dividends to members is a major factor in influencing the loyalty and willingness of members to participate and sell through cooperatives.

Storage Facility: members that have best warehouse want to sell their product to cooperatives. This helps them to realize the benefits gained from their cooperatives. It was observed in the analysis model, storage facility had a significant effect at $10 \%(p<0.063)$ and positive association with cooperatives market outlet choices. The odds 
ratio for storage facility indicates that with the assumption of other things kept constant, the probability of choosing cooperatives market outlet increases by a factor of 9.058 as storage facility increases by one unit.

\section{CONCLUSION AND RECOMMENDATIONS}

\subsection{Conclusion}

One of the challenges of perishable vegetable production is selecting appropriate market outlets to deliver the produce fresh and earn better price. Market outlet choice for smallholder potato producers is very important in the study area in particular and as a country in general, since potato is perishable horticultural crop and more demanded by the society. Therefore, enhancing Potato producers to reach the market is a key issue needed in study area.

A good market outlet is vital to increase stimulation of consumption and increase production by seeking additional output. But the Ethiopian agricultural output markets are characterized by inadequate transport service, lack of capital facilities, lack of market information, and lack of experience, weak market linkage on the input and output sides, inadequate market information, weak bargaining power of farmers, high transportation cost and lack of infrastructure. Therefore, an efficient, integrated, and responsive market outlet is a critical importance for solving those marketing problems through optimal allocation of resources in agricultural production in order to make the market efficient and to stimulate farmers' income

In conclusion, the binary logistic regression model results show that the factors found to significantly determine members' choice cooperatives as market outlet were extension service, transportation facilities and distance from market; distance from cooperatives, access to credit and belief on cooperatives; dividend and storage facility at $1 \%, 5 \%$ and $10 \%$ probability level respectively. Therefore, of the factors included in the binary logistic regression model analysis of factors determining members ${ }^{\text {ee }}$ market outlet choice, the study has shown that potato cooperatives members in the study area make their choice of market outlet for their produce based on extension service, transportation facilities, distance from market, distance from cooperatives, access to credit, belief on cooperatives, dividend and storage facility.

\subsection{Recommendations}

From the findings of this study the following recommendations were drown: 1) the government should enhance on improving rural infrastructure and developing market infrastructure in the form of establishing member collection point in order to support poor farmers for faster delivering of their product. 2) The government should invest on providing extension contact, improve road infrastructures, developing nearest potato market, potato ware house (establishing modern storage) to enhance post-harvest value addition activities and increase access market. 3) Establishing primary cooperatives societies at the area where there are no available local market for the producers/members is very important. 4) Increase awareness of members by expanding equal accessibility of market information to link members and cooperatives outlet when they produce relatively large quantity of potato. 5) If members do not belief on cooperatives, it will decrease the likelihood that they will choose cooperatives as market outlet. Therefore, the cooperatives should be initiating the members as they trust on their cooperatives. 6) The results of the study also revealed that as the access to credit of the members ${ }^{\text {ee }}$ increase, the probability of choosing cooperatives as market outlet increases. Therefore, cooperatives should be, provide credit services for the members. 7) Increase in the payment of surplus to members through dividend will increase the likelihood that members will choose cooperatives as market outlet increases. Therefore cooperatives should be, increase in the payment of surplus through dividend among members. 8) The more storage facility the members obtained, they were sending to supply more product as a result of the storage facility they have in making transaction with cooperatives. Therefore, should provide best storage facility for producers.

\section{References}

Ahmed, J., Umare, A., Mahamed, N., Galane, O., \& Desse, K. (2017). Factors affecting Groundnut market outlet choice in moisture stress area of Babile District, Eastern Ethiopia: multivariate probit approach. International Journal of Agricultural Research and Technology in Extension and Education Systems, 7(2), 91-101

Alemu G. and Gebreyohannes. (2016). Agricultural Cooperatives Sector Development in Ethiopia. Review,7(2).

Dawit Alemu, (2005). The status and challenges of agricultural marketing in Ethiopia, Melkassa agricultural research center and EARO paper presented at a panel discussion organized by the Ethiopian association of agricultural professionals (EAAP), Addis Ababa, Ethiopia. Dejene Hirpa (2014). Financial performance of primary multipurpose agricultural cooperatives and determinants of level of participation by members (Master"s thesis), Haramaya University.

Edossa TG, Zemedu L, Gesese SA (2019). Factors affecting potato market outlet choices of smallholder potato producers in Elfeta District, West Shoa Zone, Oromia Regional State, Ethiopia. J Glob Econ 7(3), pp. 338.

Ephrem, D. (2014). Assessment of members' perceptions towards factors influencing the Success of cooperatives. 
A survey of agricultural marketing cooperatives in Becho Woreda (Doctoral dissertation), Mekelle University.

Fayera Bakala and Benyam Tadesse (2019). Market chain analysis for potato: A case study in Masha District, Southwestern Ethiopia, Journal of Economics and International Business Management, Vol. 7(3), pp. 9-21.

FAO, (2010). Strengthening potato value chains: technical and policy options for developing countries (Cromme, N., A.B. Prakash, N Lutaladio, and F. Ezeta, Coordinators), Rome, p.148

FCA (Federal Cooperative Agency, 2005). Cooperative annual magazine. Addis Ababa, Ethiopia

Gildemacher P (2012). Innovation in seed potato systems in Eastern Africa. (Thesis submitted in fulfillment of the requirements of doctor), at Wageningen Uni.

Honja, T., Geta, E., \& Mitiku, A. (2017). Determinants of market outlet choice of the Smallholder mango producers: The Case of Boloso Bombe Woreda, Wolaita Zone, and Southern Ethiopia: A Multivariate Probit Approach. Global Journal of Science Frontier Research, 17(2), 23-29.

Jebesa, S. R. (2019). Determinants of smallholder farmers market participation and outlet choice decision of agricultural output in Ethiopia, A review. American Journal of Agriculture and Forestry, 7(4), 139-145.

Kahsay Gebresslasie, G., Weldewahid, D., Mohammed, D., \& Hadgu, D. (2016). Response of potato solanum tuberosum L. Varieties to Nitrogen and blended fertilizers under irrigation at Maichew, Southern Tigray, Ethiopia (Doctora Dissertation), Haramaya University.

Kirub Alemayehu Yihune (2008). Members' participation in the Awabel multi-purpose farmers' cooperatives union and its affiliates, (Master's thesis), Amhara Region, Ethiopia

Kolech, S. A., Halseth, D., De Jong, W., Perry, Wolfe, Tiruneh, F. M., \& Schulz. (2015). Potato variety diversity, determinants and implications for potato breeding Strategy in Ethiopia, American Journal of Potato Research, 92(5), 551-566.

Mokenin Aleria Negeri, (2017) Determinants of market outlet choice of coffee producing farmers in Lalo Assabi District, West Wollege Zone, Ethiopia: An econometric approach: Journal of Economics and Development, 19(2), pp,48.

Shewaye Abera (2016) Econometric Analysis of Factors Affecting Haricot Bean Market Outlet Choices in Misrak Badawacho District, Ethiopia, International Journal of Research Studies in Agricultural Sciences (IJRSAS) Volume 2, Issue 9, 2016, PP 6-12

Tarekegn, K., Haji, J., \& Tegegne, B. (2017). Determinants of honey producer market outlet choice in Chena District, southern Ethiopia: a multivariate probit regression analysis, Journal of Agricultural and food economics, 5(1), 20.

Tekle Bekele (2008). A Study on the working capital management of agricultural cooperative unions in Tigray (master's thesis), Mekelle University.

Tesfaye Assefa \& Dorsey, J. (2005), Final Evaluation Report of Agricultural Cooperatives in Tufa, A., Meuwissen, M.., Lommen, W.., Tsegaye, A., Struik, P., \& Lansink, A.(2015). Least- cost seed potato production in Ethiopia, Journal of potato research, 58(3), 277-300. Ethiopia (ACE) Program Activities.

Wainaina A.M (2016) Assessing factors affecting milk market outlet choices in WOLAITA zone, Ethiopia, Global Journal of Dairy Farming and Milk Production, Vol. 4 (10), pp. 224-232,

Wosene, G., Ketema, M., \& Ademe, A. (2018). Factors affecting market outlet choices of pepper producers in Wonberma district, Northwest Ethiopia: multivariate probit approach, cogent food \& agriculture, 4(1), 1558497.

Yemane, T. I. (1967). Statistics: An introductory analysis 2nd edition, New York. 